\title{
Study of the properties of water-swelling rubber containing gums and extelint
}

\author{
(C) Konstantin V. Efimov, Evgeny N. Egorov, Nikolay F. Ushmarin, and Nikolay I. Koltsov*' \\ Department of Physical Chemistry and Macromolecular Compounds. Chuvash State University \\ of I.N. Ulyanov. Moskovsky Ave., 15. Cheboksary, 428015. Chuvash Republic. Russia. \\ Phone: +7 (8352) 45-24-68. E-mail: koltsovni@mail.ru
}

\begin{abstract}
*Supervising author; ${ }^{+}$Corresponding author
Keywords: guar and xanthan gums, extelint fiber, caoutchoucs, water-swelling rubber, rheological and elastic-deformation properties, the degree of volumetric swelling.
\end{abstract}

Abstract
It is known that the main role in water-swellable sealing elements belongs to rubber, the properties of which depend on the nature of the rubbers and functional ingredients used. Water-swellable sealing elements are mainly made from rubbers based on acrylate, chloroprene and nitrile butadiene rubbers using various hydrophilic additives: starch derivatives, cellulose, polyvinyl alcohol and various oligomeric resins. However, after sufficiently long contact with water, some additives are washed out and the sealing properties of the sealing elements are lost. Among the promising insoluble and limited water-swellable additives, sodium polyacrylate should be distinguished. Using it as part of rubbers together with soluble water-swellable additives will allow preserving the sealing properties of the sealing elements by filling it with the pores formed when washing water-soluble swellable additives from rubbers. In this regard, in this work, the effect of guar and xanthan gums together with extelint fiber on the properties of water-swelling rubber based on a combination of nitrile butadiene $B N K S-18 A M N$, chloroprene neoprene $\mathrm{W}$, acrylate nipole AR22 and butadiene SKD caoutchoucs with sulfuric vulcanizing system, was studied. The rubber mixture was prepared by mixing rubbers with ingredients on laboratory rolls $L B 320$ 160/160. The rheological characteristics of the rubber composition were studied on an MDR 3000 Basic rheometer at $150{ }^{\circ} \mathrm{C}$. Standard samples of the rubber mixture were vulcanized at a temperature of $150^{\circ} \mathrm{C}$ for 30 minutes in a curing press type $P-V-100-3 R T-2$ $P C D$. The main properties of the vulcanizates were determined according to the standards applicable in the rubber industry. It is shown that the introduction of gums with extelite into the rubber mixture leads to a change in its rheological parameters. Vulcanizates that contain gums are characterized by lower values of conditional tensile strength and rebound elasticity, but larger elongation at break and degree of swelling in distilled and formation water compared to the vulcanizate of the base rubber mixture.

\section{References}

[1] S.I. Sandalov, M.S. Reznikov, N.F. Ushmarin, N.I. Koltsov. The influence of the composition of rubbers on the sealing ability of the sealing elements of packer-anchor equipment. Rubber and rubber. 2015. No.3. P.22-26. (russian)

[2] A.V. Ivanova, I.S. Spiridonov, N.F. Ushmarin, E.N. Egorov, N.I. Koltsov. The study of sorption properties of water-swelling rubber. XXI Intern. scientific and practical conf. "Rubber industry. Raw materials, technologies ", Moscow, May 31 - June 03, 2016. Abstracts dokl. Moscow. P.74-76. (russian)

[3] N.F. Ushmarin, D.V. Pelipenko, S.I. Sandalov, E.N. Egorov, N.I. Koltsov. Development of rubber for water-oil swellable packers. VII All-Russian Conference "Rubber and Rubber - 2017: Traditions and Innovations". Moscow, April 25-26, 2017. Reports. Moscow. 2017. P.56-57. (russian)

[4] A.V. Ivanova, E.N. Egorov, N.I. Kol'tsov, N.F. Ushmarin, S.I. Sandalov. An investigation of the effect of methyl cellulose and sodium polyacrylate on the hydrosorption properties of a vulcanisate based on chloroprene rubber. International Polymer Science and Technology. 2018. Vol.45. No.7. P.311-314.

[5] I.S. Spiridonov, N.F. Ushmarin, S.I. Sandalov, E.N. Egorov, and N.I. Koltsov. Effect of functional ingredients on the physico-mechanical and operational properties of rubber mixtures for sealing elements. Butlerov Communications. 2018. Vol.53. No.1. P.153-157. https://doi.org/10.37952/ROI-jbc-02/18-53-1153 
STUDY OF THE PROPERTIES OF WATER-SWELLING RUBBER CONTAINING GUMS AND EXTELINT

[6] E.N. Egorov, N.F. Ushmarin, S.I. Sandalov, I.S. Spiridonov, and N.I. Koltsov. The influence of functional ingredients on the technological properties of water-oil-swelling rubber sealing elements. Butlerov Communications. 2019. Vol.57. No.1. P.95-100. https://doi.org/10.37952/ROI-jbc-02/19-57-1-95

[7] E.N. Egorov, N.F. Ushmarin, S.I. Sandalov, I.S. Spiridonov, and N.I. Koltsov. The influence of functional ingredients on the physico-mechanical and operational properties of rubbers for water-oilswelling sealing elements. Butlerov Communications. 2019. Vol.57. No.2. P.68-73. https://doi.org/10.37952/ROI-jbc-02/19-57-2-68

[8] E.N. Egorov, N.F. Ushmarin, K.V. Efimov, S.I. Sandalov, I.S. Spiridonov, and N.I. Koltsov. The influence of functional ingredients on the technological properties of water-swelling rubber sealing elements. Butlerov Communications. 2019. Vol.58. No.6. P.146-151. https://doi.org/10.37952/ROI-jbc02/19-58-6-146

[9] E.N. Egorov, N.F. Ushmarin, K.V. Efimov, S.I. Sandalov, I.S. Spiridonov, and N.I. Koltsov. The influence of functional ingredients on the physico-mechanical and operational properties of rubbers for water-swelling sealing elements. Butlerov Communications. 2019. Vol.58. No.6. P.152-157. https://doi.org/10.37952/ROI-jbc-02/19-58-6-152

[10] K.V. Efimov, N.F. Ushmarin, N.I. Koltsov. The study of the properties of water-swelling rubber based on combinations of caoutchoucs. XIV International Young. scientific conf. by natural scientific and technical disciplines. Yoshkar-Ola. April 19-20, 2019. Part 3. P.36-38. (russian) 